\title{
ERRATUM TO: ESTIMATING STRUCTURAL EQUATION MODELS USING JAMES-STEIN TYPE SHRINKAGE ESTIMATORS
}

\author{
Elissa Burghgraeveid, Jan De Neveid and Yves Rosseel[ \\ GHENT UNIVERSITY
}

Erratum to: PSYCHOMETRIKA-VOL. 86, NO. 1, 96-130 MARCH 2021

https://doi.org/10.1007/s11336-021-09749-2

The original version of the article has contained a mistake in author affiliation that rather (Ghent University), the address (Henri Dunantlaan 1) is filled in beneath the authors names.

The correct affiliation is given below.

Elissa Burghgraeve, Department of Data Analysis, Ghent University, Ghent, Belgium.

Publisher's Note Springer Nature remains neutral with regard to jurisdictional claims in published maps and institutional affiliations.

Published Online Date: 5 MAY 2021

The original article can be found online at https://doi.org/10.1007/s11336-021-09749-2.

Correspondence should be made to Elissa Burghgraeve, Department of Data Analysis, Ghent University, Ghent, Belgium. Email: Elissa.Burghgraeve@UGent.be 